\title{
KEANEKARAGAMAN JENIS DAN KEPADATAN GASTROPODA DI BERBAGAI SUBSTRAT BERKARANG DI PERAIRAN PANTAI TIHUNITU KECAMATAN PULAU HARUKU KABUPATEN MALUKU TENGAH
}

\author{
Marlen Persulessy ${ }^{1}$, Ine Arini ${ }^{2}$ \\ ${ }^{1}$ Alumni Program Studi Pendidikan Biologi \\ ${ }^{2}$ Dosen Program Studi Pendidikan Biologi \\ E-mail: arini_ine@yahoo.com
}

\begin{abstract}
Background: Indonesia has a very high diversity of flora and fauna, including various marine biota. The diversity of marine biota varies greatly and can represent all phyla in the Pacific region of Indonesia. The purpose of this study was to determine the environmental factors, the value of diversity and the density of gastropods in the coastal waters of Tihunitu.

Methods: This study was conducted on July 19, 2018. The type of research used is a descriptive type of research to see the value of diversity and density.

Results: The measurement of environmental factors shows that the temperature values on transect I range from $26.5-28,{ }^{\circ} \mathrm{C}$. The second transect ranged from $27.1-29.7,{ }^{\circ} \mathrm{C}$. The transect III ranges from 28.0-29.8, ${ }^{\circ} \mathrm{C}$. The $\mathrm{PH}$ value on transect I ranges from 7.4-74. The transect II ranges from 7.2-7.4. The transect III ranges from 7-7.3. The salinity value on transect I ranged from 24-34 (\%o). The transect II ranges from 26-39 (\%o). The transect III ranges from 25-29 (\%). The value of dissolved oxygen on transect I ranged from 7.3 to $8.3 \mathrm{mg} / 1$. On transect II ranged from $6.9-723 \mathrm{mg} / 1$. The transect III ranges from 7.1-7.2 $\mathrm{mg} / 1$. While the results of determining the type of substrate visually descriptive showed that Tihun Beach has 2 types of substrate types, namely sandy and rocky.

Conclusion: Gastropods found in Tihun coastal waters are 37 species representing 14 families in the phylum of molluscs. With the average value of diversity in the research station is classified as moderate, namely $3,448.6$. The highest density value is 0.108 and the lowest density value is 0.01 .
\end{abstract}

Keywords: Physical - chemistry factors, diversity, density, gastropods

\begin{abstract}
Abstrak
Latar Belakang: Indonesia memiliki Keanekaragaman flora dan fauna yang sangat tinggi, termasuk keanekaragam biota bahari. Keanekaragaman biota bahari sangat bervariasi dan dapat mewakili seluruh filum yang ada di wilayah Pasifik Indonesia. Tujuan penelitian ini adalah untuk mengetahui faktor lingkungan, nilai keanekaragaman dan kepadatan gastropoda di perairan pantai Tihunitu.

Metode: Penelitian ini dilakukan pada tanggal 19 Juli 2018. Tipe penelitian yang digunakan adalah tipe penelitian deskriptif untuk melihat nilai keanekaragaman dan kepadatan.

Hasil: Pada pengukuran faktor lingkungan menunjukkan bahwa nilai suhu pada transek I berkisar antara $26,5-28,{ }^{\circ} \mathrm{C}$. Pada transek kedua berkisar antara $27,1-29,7,{ }^{\circ} \mathrm{C}$. Pada transek III berkisar antara $28,0-$ $29,8,{ }^{\circ} \mathrm{C}$. Nilai PH pada transek I berkisar antara 7,4-74. Pada transek II berkisar antara 7,2-7,4. Pada transek III berkisar antara 7-7,3. Nilai salinitas pada transek I berkisar antara 24-34 (\%o). Pada transek II berkisar antara 26-39 (\%o). Pada transek III berkisar antara 25-29 (\%). Nilai oksigen terlarut pada transek I berkisar antara 7,3-8,3mg/1. Pada transek II berkisar antara 6,9-723 mg/1. Pada transek III berkisar antara 7,1-7,2 mg/1. Sementara hasil penentuan jenis substrat secara visual deskriptif menunjukkan Pantai Tihunitu memiliki 2 jenis tipe substrat yaitu berpasir dan berkarang.

Kesimpulan: Gastropoda yang ditemukan pada perairan pantai Tihunitu 37 jenis yang mewakili 14 famili pada filum molusca. Dengan nilai rata- rata keragaman pada stasium penelitian tergolong sedang yaitu 3,448.6. Nilai Kepadatan tertinggi yaitu 0.108 dan nilai kepadatan terendah yaitu 0,01 .
\end{abstract}

Kata Kunci: Faktor fisika-kimia, keanekaragaman, kepadatan, gastropoda 
Biopendix, Volume 5, Nomor 1, Oktober 2018, hlm. 45-52

\section{PENDAHULUAN}

Indonesia memiliki Keanekaragaman flora dan fauna yang sangat tinggi, termasuk keanekaragam biota bahari. Keanekaragaman biota bahari sangat bervariasi dan dapat mewakili seluru filum yang ada di wilayah Indonesia- pasifik. Menurut Mudjiono (2010). Gastropoda merupakan kelas moluska yang paling sukses karena menguasai berbagai habitat yang ber-variasi. Kelas Gastropoda umumnya lebih dikenal dengan sebutan siput atau keong. Tubuh Gastropoda sangat bervariasi dalam bentuk dan ukurannya. Gastropoda memiliki cangkang tunggal berulir, kepala yang berkembang baik, dilengkapi dengan tentakel dan mata.

Gastropoda memiliki nilai penting secara ekonomi karena cangkangnya dapat digunakan untuk berbagai hiasan yang mahal dan dagingnya sebagai sumber bahan makanan.

Gastropoda juga merupakan organisme kunci dalam rantai makan di ekosistem perairan.Keberadaan Gastropoda di dalam ekosistem dapat mempengaruhi kehidupan biota lain. Selain menjadi mangsa bagi biota lain, dalam suatu rantai makanan Gastropoda dapat berperan sebagai herbivora (grazer), karnivora, scavenger, detritivor, deposit feeder, suspension feeder dan parasit. Gastropoda yang hidup di perairan umumnya ditemukan sebagai detritivor. Dalam rantai makanan, detritivor berperan sebagai pengubah detritus yang memiliki tingkat energi rendah menjadi trofik dengan tingkat energi yang lebih tinggi (Sinyo, 1983).

Gastropoda (keong) hewan bertubuh lunak yang mempunyai cangkang di luar tubuh tempatnya berlindung ketika bahaya datang. Walaupun begitu, ada juga Gastropoda yang tidak mempunyai cangkang atau bercangkang kecil sehingga tidak dapat menampung seluruh tubuhnya. Sepintas, Gastropoda dapat dibedakan degan binatang lainnya karena ia mempunyai satu atau dua pasang antena pada bagian kepalanya, bergantung pada klasifikasinya. Ketika ia bergerak terlihat jejaknya berupa segaris lendir yang berasal dari lendir tubuhnya. Tubuh Gastropoda diselimuti lendir agar tidak mengering yang dapat Gastropoda mengakibatkan kematiannya Harminto, (2003). Gastropoda dapat ditemukan di mana-mana di dunia ini karena mereka hidup mulai dari puncak gunung yang tinggi sampai di dasar laut. Gastropoda terestrial dapat ditemukan di puncak gunung sampai pada bagian belakang hutan mangrove. Umumnya mereka hidup menempel pada pohon, semak, batu, batang pohon roboh, dan serasah. Sebagian besar terestrial hidup di serasah, terutama serasah yang tebal.Gastropoda terestrial berfungsi amat penting dalam lingkungannya karena mereka menempati semua relung lingkungan sebagai pemakan, mangsa, dan pendaurulang.

Perairan pantai Tihunutu merupakan perairan pantai yang cukup baik karena memiliki karakteristik prairan pantai yang indah. Selanjutnya lingkungan pesisir dapat di katakana prodiktif yang mana memperlihatkan berbagai jenis sumber daya yang dapat dimanfatkan secara terus menerus dengan adanya berbagai jenis organisme laut atau biota laut seperti Gastropoda dan jenis yang lainnya. Hal ini tidak terlepas dari mata pencaharian masyarakat sekitar sebagain besarnya sebagai nelayan. Namun keberadaan biotabiota laut, seperti Gastropoda pada pesisir pantai Tihunitu ini sering kali di abaikan. Kegiatan berlebihan seperti, pembuangan limbah yang sering dilakukan oleh masyarakat setempat yang berada di sekitar wilayah pesisir pantai atau pengambilan biota-biota laut di kawasan pesisir pantai Tihunitu secara berlebihan dapat menyebabkan penurunan populasi maupun Keanekaragaman Jenis serta Kepadatan Gastropoda yang berada di sekitar daerah pesisir pantai. Sehingga secara langsung mengganggu kestabilan ekologis di sekitar perairan pantai Tihunitu. Namun, jika dilakukan upaya-upaya untuk melestarikan biota-biota laut seperti Gastropoda di wilayah pesisir pantai, maka populasi Gastropoda di desa setempat dapat terlindungi. Salah satunya adalah dengan memberikan informasi kepada masyarakat sebagai pengelola wilayah pesisir seperti pemerintah desa setempat, agar nantinya pemerintah 
Biopendix, Volume 5, Nomor 1, Oktober 2018, hlm. 45-52

desa beserta masyarakat dapat bersamasama untuk menjaga dan melestarikan Gastropoda yang ada di daerah pesisir pantai.

\section{MATERI DAN METODE}

Tipe penelitian yang digunakan dalam pendekatan ini adalah deskritif yaitu mengungkapkan informasi secara deskritif tentang keanekaragam jenis dan kepadatan Gastropoda di perairan Pantai Tihunitu Kecamatan Pulau Haruku Kabupaten Maluku Tengah. Jenis penelitian yang di gunakan adalah line transek.

Populasi dalam penelitian ini adalah seluruh Gastropoda yang terdapat pada Perairan Pantai Tihunitu Kecamatan Pulau Haruku Kabupaten Maluku Tengah.

Sampel dalam penelitian ini adalah jenis-jenis Gastropoda yang terdapat dalam petak cuplikan dengan teknik purposive sampling. Pengambilan sampel secara purposive adalah teknik penentuan sampel dengan pertimbangan tertentu oleh peniliti Dharma (1992). Jenis-jenis Gastropoda yang di temukan pada kudrat dianggap telah mewakili populasi Gastropoda yang ada di perairan pantai Tihunitu. Untuk mengukur oksigen terlarut menggunakan alat DO meter dan untuk substrat, nantinya di ambil sampel pada tiap- tiap plot dengan cara visual deskritif untuk menentukan jenis substratnya

\section{HASIL DAN PEMBAHASAN \\ Hasil \\ Data Kondisi Faktor Lingkungan Pada Kondisi Penelitian}

Faktor lingkungan baik fisik maupun kimia yang di ukur dalam penelitian ini yaitu suhu, $\mathrm{pH}$ salinitas, oksigen terlarut (DO). Pengukuran faktor lingkungan dilakukan bersamaan dengan pengumpulan data jenis Gastropoda di setiap transek pada plot pada stasium pengamatan.

\section{Suhu}

Hasil pengukuran suhu pada stasium pengamatan di Perairan pantai Tihunitu menunjukan, suhu tertinggi pada saat pengambilan sampel terdapat pada transek III plot 1 yaitu $29,8^{\circ} \mathrm{C}$, sedangkan suhu terendah terdapat pada transek 1 plot 3 yaitu $26,5^{\circ} \mathrm{C}$.

Tabel 1. Hasil Pengukuran Suhu Air Laut ${ }^{\circ} \mathrm{C}$ (Plot).

\begin{tabular}{cccc}
\hline \multirow{2}{*}{ Transek } & \multicolumn{3}{c}{ Plot } \\
\cline { 2 - 4 } & $\mathbf{1}$ & $\mathbf{2}$ & $\mathbf{3}$ \\
\hline I & 28,0 & 27,3 & 26,5 \\
II & 29,7 & 28,8 & 27,1 \\
III & 29,8 & 29,6 & 28,0 \\
\hline
\end{tabular}

$\mathrm{pH}$

Hasil pengukuran $\mathrm{PH}$ pada lokasi stasium pengamatan di Perairan Pantai Tihunitu menunjukan, $\mathrm{pH}$ tertinggi yaitu 7,4 dan $\mathrm{pH}$ terendah terdapat pada Setiap transek yaitu 7 (4.2).

Tabel 2. Hasil Pengukuran pH Air Laut (Plot).

\begin{tabular}{cccc}
\hline \multirow{2}{*}{ Transek } & \multicolumn{3}{c}{ Plot } \\
\cline { 2 - 4 } I & $\mathbf{1}$ & $\mathbf{2}$ & $\mathbf{3}$ \\
\cline { 2 - 4 } II & 7,4 & 7,4 & 7,4 \\
III & 7,4 & 7,2 & 7,2 \\
\hline
\end{tabular}

\section{Salinitas}

Hasil pengukuran salinitas pada lokasi stasium pengamatan di perairan Pantai Tihunitu menunjukan, salinitas tertinggi terdapat pada transek II plot 3yaitu 39 (\%o) dan salinitas terendah terdapat pada transek I plot I yaitu $24(\%)$.

Tabel 3. Hasil Pengukuran Salinitas Air Laut (\%) (Plot).

\begin{tabular}{cccc}
\hline \multirow{2}{*}{ Transek } & \multicolumn{3}{c}{ Plot } \\
\cline { 2 - 4 } & $\mathbf{1}$ & $\mathbf{2}$ & $\mathbf{3}$ \\
\hline I & 24 & 34 & 32 \\
II & 26 & 30 & 39 \\
III & 29 & 25 & 29 \\
\hline
\end{tabular}




\section{Oksigen Terlarut (DO)}

Bedasarkan pengukuran oksigen terlarut air laut pada stasium pengamatan di antai Tihuniu, menunjukan bahwa tingkat oksigen terlarut $(\boldsymbol{D O})$ tertinggi terdapat pada transek I plot 3 yaitu $8,3 \mathrm{mg} / 1$, dan yang terendah terdapat pada transek II plot 1 yaitu $6,9 \mathrm{mg} / 1$.

Tabel 4. Hasil Pengukuran DO Air Laut Mg/1 (Plot).

\begin{tabular}{cccc}
\hline \multirow{2}{*}{ Transek } & \multicolumn{3}{c}{ Plot } \\
\cline { 2 - 4 } & $\mathbf{1}$ & $\mathbf{2}$ & $\mathbf{3}$ \\
\hline I & 7,3 & 7,4 & 8,3 \\
II & 6,9 & 7,2 & 7,1 \\
III & 7,1 & 7,1 & 7,2 \\
\hline
\end{tabular}

\section{Substrat}

Hasil pengamatan jenis substrat secara visual deskritif pada 3 transek pengamatan di Perairan Pantai Tihunitu di peroleh 2 tipe substrat yaitu berpasir dan berkarang. Pada plot 1dan 2 di setiap transek di dominasi oleh jenis substrat berkarang.sedangkan plot 3 jenis substratnya lebih didominsi oleh substrat berpasir.

Tabel 5. Pengambilan Jenis Substrat (Plot)

\begin{tabular}{clll}
\hline \multirow{2}{*}{ Transek } & \multicolumn{3}{c}{ Plot } \\
\cline { 2 - 4 } & \multicolumn{1}{c}{$\mathbf{1}$} & \multicolumn{1}{c}{$\mathbf{2}$} & \multicolumn{1}{c}{$\mathbf{3}$} \\
\hline I & berbatu & Berkarang & Berbatu \\
II & Berkarang & Berbatu & Berbatu \\
III & Berkarang & Berkarang & Berkarang
\end{tabular}

\section{Indeks Keanekaragaman Jenis Gartropoda Pada Transek 1}

Indeks

Keanekaragaman

jenis

Gastropoda pada kawasan pesisir pantai Tinuhitu Kecamatan Pulau Haruku, Kabupaten Maluku Tengah untuk setiap jenisnya mempunyai nilai yang berbedabeda. Pada transek Pertama indeks keanekaragaman yang tertinggi yaitu sebesar 0,351, dan indeks keanekaragaman yang terendah yaitu sebesar 0,039. Rata- rata indeks keanekaragaman jenis Gastropoda pada transek I yaitu 2,125.
Indeks Keanekaragaman Jenis Gartropoda Pada Transek 2

Indeks Keanekaragaman jenis Gastropoda pada transek 2 tingkat keanekaragaman yang tertinggi sebesar 0,357, dan indeks keanekaragaman yang terendah yaitu sebesar 0,057. Rata- rata indeks keanekaragaman jenis Gastropoda pada transek I yaitu 1,968.

\section{Indeks Keanekaragaman Jenis Gartropoda Pada Transek 3}

Indeks Keanekaragaman Jenis

Gastropoda pada transek 3 tingkat keanekaragaman yang tertinggi sebesar 0,344, dan indeks keanekaragaman yang terendah yaitu sebesar 0,045. Rata- rata indeks keanekaragaman jenis Gastropoda pada transek I yaitu 2,160.

Dari uraian tentang keanekaragaman Jenis Gastropoda pada ke tiga transek di perairan pantai Tinihitu Kecamatan Pulau Haruku Kabupaten Maluku Tengah dapat dihitung nilai rata-rata untuk indeks keanekaragaman jenis Gastropoda di lokasi penelitian. Indeks keanekaragaman jenis Gastropoda pada Lokasi penelitian yaitu 208

\section{Kepadatan Jenis Gastropoda}

Hasil perhitungan nilai kepadatan Gastropoda pada Perairan Pantai Tihunitu Kecamatan Pulau Haruku Kabupaten Maluku Tengah memiliki nilai yang bervariasi pada Lokasi penelitian. dimana jenis Gastropoda Natica zonalisis dan Conus ebraus memiliki kepadatan tertinggi dibandingkan dengan jenis yang lainnya yaitu mencapai 018, sementara jenis Gastropoda yang memiliki nilai kepadatan terendah terdiri dari Cyprea annus, Nerita Albicilla, dan Rhinodaris Vertagus dengan nilai kepadatan 0,01.

\section{Pembahasan}

Kondisi Faktor lingkungan di daerah perairan pantai Tinuhitu Kecamatan Pulau Haruku Kabupaten Maluku Tengah. Hasil pengukuran suhu air laut pada saat pengambilan sampel Gastropoda pada transek I memiliki kisaran nilai suhu antara 26,5-28, pada transek ke II nilai suhu berkisar antara 27,1-29,7 pada transek III kisaran nilai 
suhu berkisar antara 28-29,8. Suhu pada perairan pantai Tihunitu merupakan suhu optimal bagi perkembangan dan pertumbuhan Gastropoda. Hal tersebut sesuai dengan pendapat Sutinko, (1995) yang menyatakan bahwa suhu sangat berpengaruh terhadap proses metabolisme suatu organisme, Gastropoda dapat melakukan proses metabolisme secara optimal pada kisaran suhu antara 25-32.

Pernyataan yang sama juga di perkuat oleh Munarto (2010) yang menjelasakan bahwa perubahan suhu berpengaruh terhadap jenis organisme yang dapat hidup dan bertahan pada wilayah perairan tertentu, serta aktifitas suatu organisme. Semakin tinggi suhu pada suatu perairan, maka semakin sedikit oksigen yang larut dalam air. Suhu yang tinggi akan menurunkan jumlah oksigen yang terlarut dalam air, akibatnya Gastropoda dan organisme air lainnya akan mati karena kurangnya oksigen. Suhu air yang relatif tinggi pada suatu perairan ditandai dengan munculnya ikan dan organisme laut lainnya ke permukaan untuk mencari oksigen.

Faktor lingkungan berikutnya adalah $\mathrm{pH}$, menurut Odum (1996) menyatakan bahwa $\mathrm{pH}$ merupakan faktor pembatas bagi organisme dalam suatu perairan dengan $\mathrm{pH}$ yang terlalu tinggi atau rendah, akan mempengaruhi ketahanan hidup organisme yang hidup dalam perairan. sebagian biota akuatik sensitif terhadap perubahan $\mathrm{pH}$ dan menyukai kisaran $\mathrm{pH}$ sekitar $7-8,5$. Pada lokasi penelitian terlihat jelas bahwa kisaran nilai $\mathrm{pH}$ pada transek dan kuadran pengamatan sampel Gastropoda berkisar antara 7-7,4 dan kisaran nilai ph tersebut tergolong dalam kategori netral dan menunjang pertumbuhan dan perkembangan Gastropoda. Menurut Dahuri,(2003). Gastropoda dapat bertumbuh dengan baik pada kisaran $\mathrm{pH} 6-7$.

Ariska, (2012) menambahkan bahwa nilai $\mathrm{pH}$ yang rendah menyebabkan menurunnya jumlah oksigen terlarut pada suatu perairan, sehingga menyebabkan aktifitas pernafasan Gastropoda meningkat dan selera makan menurun. Hal sebaliknya terjadi pada perairan yang memiliki nilai $\mathrm{pH}$ yang tinggi dapat menyebabkan kadar amonia meningkat, sehingga secara tidak langsung telah membahayakan organisme yang berada pada perairan tersebut.

Faktor berikutnnya yang juga penting adalah salinitas, salinitas adalah jumlah garam terlarut dalam 1000 gram air laut. Salinitas menggambarkan padatan total dalam air setelah karbonat dikonfensi menjadi oksida, semua bromida dan iodida digantikan oleh klorida dan semua bahan organik yang telah dioksidasi. Salinitas juga merupakan salah satu parameter yang berperan penting dalam kehidupan di laut karena perubahan salinitas dapat mempengarui kepadatan dari suatu organisme di perairan Odum, (1996) Pada lokasi penelitian terlihat jelas bahwa pengukuran salinitas pada Lokasi pengamatan pada transek I pengambilan sampel Gastropoda memiliki kisaran nilai salinitas antara 24-32, pada transek ke II nilai suhu berkisar antara 26-39 pada transek III kisaran nilai suhu berkisar antara 25-29. Apabila dilihat dari kisaran salinitasnya maka dapat dikatakan bahwa salinitas pasa perairan pantai Tinuhitu sangat ideal untuk pertumbuhan biota-biota laut, seperti Gastropoda. Ariska, (2012) menyatakan bahwa Gastrpoda umumnya mentoleransi salinitas berkisar antara 25-40 ppt. Karena pengaruh salinitas secara tidak langsung mengakibatkan adanya perubahan komposisi dalam suatu ekosistem.

Faktor lingkungan yang berikutnya yaitu oksigen terlarut. Oksigen terlarut merupakan salah satu faktor penting untuk pertumbuhan biota-biota laut, seperti Gastropoda. Fardiaz (1992) dalam Munarto (2010) mengatakan bahwa oksigen terlarut merupakan kebutuhan dasar untuk kehidupan tumbuhan dan hewan di dalam air. Kehidupan organisme di dalam air tersebut tegantung dari kemampuan air untuk mempertahankan konsentrasi oksigen minimal yang dibutuhkian untuk kehidupannya. Pada lokasi penelitian, oksigen terlarut yang diukur pada lokasi penelitian berkisar antara 6,9-8,3 mg/l. Menurut Saptarini,dkk (2010). menyatakan bahwa standar Oksigen terlarut untuk prairan yang mengandung kehidupan sebesar $5 \mathrm{mg} / \mathrm{l}$ 
dan untuk mendukung kehidupan biologi secara normal air harus cukup mengandung oksigen terlarut sebesar 5-7 mg/l menunjukan bahwa perairan yang bersangkutan dalam keadaan baik untuk perkembangan hewan benthos Odum, (1998). Munarto (2010), menyatakan bahwa pada perairan dengan kandungan oksigen teralrut rendah, kondisi suatu perairan dapat menjadi anaerob, sehingga menganggu kehidupan Gastropoda pada suatu perairan Irwarna, (2008). juga menambahkan bahwa sudah cukup untuk memenuhi kehidupan organisme karena kandungan Oksigen terlarut di dalam air 2 $\mathrm{mg} / \mathrm{l}$.

Faktor lingkungan selanjutnya yaitu substrat. Tipe substrat merupakan faktor utama yang sangat mempengaruhi penyebaran Gastropoda. Selain itu, tipe substrat juga berkaitan dengan ketersediaan nutrisi dalam sedimen. Karyanto, (2004). menyatakan bahwa distribusi dan kelimpahan jenis Gastropoda dipengaruhi oleh diameter rata-rata butiran sedimen. Berdasarkan hasil penelitian di perairan pantai Tinuhitu memiliki 2 tipe subsrtrat berkarang dan berpasir.subsrtrat pada transek I plot 1 dan plot 2,3 berkarang. Pada transek II plot 1 dan plot 2 dan 3 tipe substrat berpasir, pada transek III plot 1 dan plot 2,3, tipe substrat berkarang. Tipe substrat perairan pantai Tinuhitu yaitu substrat berkarang terdapat pada transek $1,2,3$, tetapi hanya plot 1 . pada ketiga transek pengamtan ditemukan ada 6 spesies Gastropoda dengan jumlah individu sebanyak 15 individu. Spesies Gastropoda yang ditemukan pada substrat berkarang yaitu, Cypraea annulus, Nerita abacilla, Nerita chameleon sedangkan untuk substrat berbatu pada transek 3 plot 2 dan 3 ditemukan 4 spesies Gastropoda dengan jumlah individu sebanyak 12 yang hidup pada tipe substrat ini diantaranya yaitu Conus ebraus, Cyprea amulus, Morula granulate, Thais tuberosa.

Dari Semua spesies yang ditemukan pada lokasi penelitian perairan pantai Tinuhitu jenis Gastropoda yang lebih mendominas yaitu Nerita albacilla dan Cyprea annulus dengan jumlah 65 yang menyebar pada transek pertama dan kedua pada Lokasi peneltian. Odum (1993) dalam Sinyo dkk, (2013), menyatakan bahwa organisme yang memiliki nilai kepadatan tinggi menunjukan bahwa jenis organisme tersebut memiliki kemampuan beradapatasi dengan lingkungan yang di tempatinya, sehingga memiliki kemampuan reproduksi yang tinggi. Lebih lanjut dinyatakan oleh Rahmawati, (2014) organisme yang memiliki nilai kepadatan tinggi menunjukan bahwa jenis tersebut memiliki kemampuan menempati ruang yang lebih luas sehingga kesempatan untuk berkembang semakin luas.

Dari penelitian yang dilakukan di pantai Tinuhitu, secara keseluruhan dari 3 transek ditemukan 37 Jenis Gastropoda yang mewakili 14 famili pada filum mollusca, diantaranya yaitu Famili Architectonidae, Famili Buccinidae, Famili Bursinidae, Famili Cerithidae, Famili Conidae, Cypracidae, Fasciollaridae, Famili Muricidae, Famili Neritidae, Famili Nassaridae, Famili Naticidae, Famili Turbinidae, dan Famili Trochidae. Pada transek pertama di temukan 15 jenis Gastropoda. spesies yang ditemukan yang lebih mendominasi yaitu Nerita albacilla dengan jumlah spesies yaitu 65. Sedangkan yang terendah yaitu Conus lividus, Drupa morum, Thais tuberosa,dengan jumlah spesies yaitu 2. Secara keseluruhan jumlah spesies pada transek pertama yaitu 247.

Pada transek kedua ditemukan 10 jenis Gastropoda .Pada transek kedua ini jenis yang sangat mendominasi yaitu dengan jumlah spesies yaitu 65 , sedangkan jenis yang terendah yaitu Drupa morum dengan jumlah spesies yaitu 3. Secara keseluruhan jumlah spesies pada transek kedua yaitu 230 . Pada transek ketiga ditemukan 12 jenis Gastropoda. Pada transek ketiga ini jenis yang sangat mendominasi yaitu Stombus $s p$ dengan jumlah yaitu 35 , sedangkan jenis yang terendah yaitu Mitra retusa dengan jumlah spesies yaitu 2. Secara keseluruhan jumlah spesies pada transek ketiga yaitu 205.

Dari uraian tentang jenis Gastropoda yang dikemukakan pada ketiga transek di perairan pantai Tinuhitu menunjukan bahwa nilai rata-rata indeks keanekaragaman 
Gastropoda pada transek I, II, dan III, tergolong sedang, berdasarkan, nilai keanekaragaman $\mathrm{H}^{\prime}$ pada transek I,II, dan III berkisar antara 1,00-3,00. Irawan (2008) menjelaskan hal ini dikarenakan jumlah spesies yang menempati daerah tersebut tidak banyak jenisnya serta individu-individu yang menempati habitat tersebut bersifat khas, sehingga keanekaragaman pada ketiga transek tersebut tergolong dalam kategori sedang. Sementara itu, nilai rata-rata indeks keanekaragaman jenis Gastropoda pada Lokasi penelitian secara menyeluruh yaitu 2084,33. Nilai rata-rata pada Lokasi penelitian tergolong dalam kategori sedang, hal ini dikarenakan jumlah sepesies yang mendominasi pada tiap-tiap transek pada lokasi penelitian ini jumlanya tidak terlalu banyak, dan tidak terlalu sedikit atau tergolong sedang. Hal yang sama diungkapkan Rakhmanda, (2011). menyatakan bahhwa suatu komunitas diakatakan mempunyai keanekaragaman jenis yang tinggi jika komunitas disusun oleh banyaknya spesies, dengan kata lain bahwa nilai indeks keanekaragaman sangat dipengarui oleh jumlah spesies dan jumlah total individu masing-masing spesies pada suatu komunitas. Sebaliknya, jika komunitas itu disusun ole sangat sedikit dan jika hanya sedikit jenis yang dominan maka keanekaragaman jenisnya rendah.

Berdasarkan pernyataan tentang indeks keanekaragaman di pesisir pantai Tinuhitu terlihat pada ketiga transek bahwa faktor fisik kimia pun tidak terlalu memberikan pengaruh terhadap penurunan tingkat keanekaragaman jenis Gastropoda. Karena berdasarkan hasil pengukuran faktor fisik-kima baik meliputi suhu, $\mathrm{pH}$, salinitas, oksigen terlarut maupun substrat dasar, menunjukan angka yang optimal dan normal untuk perkembangbiakan dan pertumbuhan Gastropoda. Jadi, dapat dikatakan bahwa faktor lingkungan tidak terlalu memberikan pengaru terhadap keanekaragaman jenis Gastropoda di perairan pantai Tinuhitu. Dari informai yang diperoleh dari warga di sekitar pesisir pantai Tinuhitu, Gastropoda sering di konsumsi oleh masyarakat di sekitar pesisir pantai Tinuhitu, saat kondisi Laut tidak memungkinkan mereka untuk melaut. Walaupun kaya akan jenis Gastropoda, namun dominan tiap spesiesnya pada Lokasi penelitian tidak terlalu banyak. Hal ini yang mungkin menyebabkan sehingga nilai indeks keanekaragaman jeni Gastropoda pada perairan pantai Tinuhitu tergolong sedang

Kepadatan Gastropoda menunjukan jumlah individu yang hidup pada habitat tertentu, luasan tertentu, dan waktu tertentu dalam Irawan (2008) menyatakan bahwa, nilai kepadatan menjadi parameter terhadap kualitas tertentu. Nilai kepadatan yang tinggi menunjukan jumlah organisme yang banyak. Hal ini mengindikasikan bahwa habitat tersebut dapat di tempati oleh organisme dalam jumlah banyak. Kepadatan jenis Gastropoda pada Lokasi penelitian berkisar antara 0,086-2,792 ind $/ \mathrm{m}^{2}$. Kepadatan tertinggi ditempati oleh jenis Gastropoda Nerita albacilla dan Cypraea annulus. Sedangkan, untuk kepadatan terendah ditempati oleh jenis Gastropoda Conus lividus, Drupa morum, Thais tuberosa. Jenis Cypraea annulus dan Nerita albacilla merupakan jenis Gastropoda dari famili Naticidae dan cypraea yang paling mendominasi Loksi penelitian ini. Sebagian besar jenis $N$. Zonalisis, dan N. Albacilla ditemukan pada substrat berbatu dan berkarang. Hal ini sesuai dengan pernyataan Irawan (2008) bahwa tipe substrat berpasir memudahkan molluska untuk mendapatkan suplai nutrisi dan air yang diperlukan untuk kelangsungan hidupnya. Sehingga banyak Gastropoda yang menyukai substrat yang banyak mengandung pasir, termasuk dan Cypraea annulus Nerita albacilla.

\section{KESIMPULAN}

Berdasarkan hasil penelitian yang telah dilakukan di perairan pantai Tinuhitu, Kecamatan Pulau Haruku, Kabupaten Maluku Tengah, maka dapat di simpulkan bahwa 1) faktor lingkungan meliputi suhu, $\mathrm{pH}$, salinitas, oksigen terlarut dan jenis substrat pada perairan pantai Tinuhitu menunjukan kisaran toleransi yang normal atau optimal untuk pertumbuhan dan perkembangbiakan jenis Gastropoda; 2) Jenis Gastropoda yang 
ditemukan pada lokasi penelitian berjumlah 37 spesies Gastropoda yang mewakili 14 famili Gastropoda; 3) Nilai keanekaragaman Gastropoda pada Lokasi penelitian termasuk dalam kategori sedang yaitu 2804,33. Sementara untuk nilai kepadatan jenis Gastropoda, jenis yang paling dominan yaitu Cypraea annulus dan Nerita albicilla dengan nilai kepadatan $0.108 \mathrm{ind} / \mathrm{m}^{2}$.

\section{DAFTAR PUSTAKA}

Ariska 2012.Keanekaragaman dan distribusi Gastropoda dan bilvavia (Moluska) di Muara Karang Tirta pangandaran. Skripsi. Bogor: Institut Pertanian Bogor.

Dharma 1992. Siput dan Kerang Indonesia (Indonesian Shells II). Wiesbaden, Hemmen 135 hlm. Jakarta: PT. Sarana Graha.

Dahuri 2003. Keanekaragaman hayati laut; Aset Pembangunan Berkelanjutan. Jakarta: PT. Gramedi pustaka Utama.

Frith, 1997. Premilinary List of Macrofauna from a Mangrove Fprest and Adjacent Biotipes at Surin Island. Phuket Marine Biology Centre Research Bulleti. Goldman, home 1983.

Harminto 2003. Taksonomi Avertrebata. Jakarta: penerbit Universitas terbuka.

Handayani, 2006. Keanekaragaman jenis Gastropoda Di Pantai Randusanga Kabupaten Brebes Jawa Tengah. Skripsi (http:/www.lib.unnes.ac.id diakses tanggal 22 Februari 2016). Universitas Negeri Semarang.

Irawan.2008. Struktur Komunitas Moluska (Gastropoda dan Bivalvia) serta Distribusinya di Pulau Burung dan Pulau Tikus, Gugusan Pulau Pari.

Karyanto. 2004. Variasi cangkang Gastropoda Ekosistem Mangrove Cilacap Sebagai Alternatif Sumber Pembelajaran Moluska; Gastropoda. Bioedukasi Volume 1 No. 1 halaman 1-6.

Kastoro, 1992. Bebarapa Aspek Biologi dan Ekologi Jenis-jenis Moluska Laut Komersial Yang Diperlukan Untuk Menunjang Usaha Budidaya. Balibang Pertanian Balai Penelitian dan Pengembangan Biologi.
Mudjiono. 2010. Mudwhelks (Gastropoda Potamididae) from Mangroves of ujung kulon National Park, Banten. Jurnal Biologi 13 (2)

Munarto 2010 Studi komunitas Gastropoda di situ Salam kampus universitas depok.skripsi. Depok: Universitas Indonesia.

Nurjanah, dkk. 2013. Keanekaragaman Gastropoda di Padang Lamun Perairan Kelurahan Senggarang Kota Tanjung Pinang Provinsi Kepulauan Riau. www.umrah.ac.id.

Odum, 1996. Dasar-dasar Ekologi. (Terjemahan). Yogyakarta: Gajah Mada University Press.

Odum, 1998. Dasar-dasar Ekologi. Terjemahan T. Samingan dan B. Srigdanono. Gajah Mada Press. Yogyakarta. Pieter, 2013. Biodiversitas kerang oyster (Mollusca, Bivalvia) di Daerah Intertidal Halmahera Barat, Maluku Utara. Jurnal IImiah Platax Vol. I-2, Januari 2013 ISSN: 2302-3589.

Rakhmanda, 2011. Estimasi Populasi Gastropoda di Sungai Tambak Bayan Yogyakarta. Jurnal Ekologi Perairan Laboratorium Ekologi Perairan Jurusan Perikanan Fakultas Pertanian UGM Th 2011 No. 1: 1-7.

Rahmawati 2014. Analisis tingkat pencemaran bedasarkan indeks keragaman populasi Gastropoda di bagian tengah sungai Tambak Bayan Yogyakarta.jurnal penelitian Yogyakarta: UIN Sunan Kalijaga.

Sutikno, 1995. Karakteristik Gastropoda. htpp://2.bp.blogspot.com/morfologi Gastopoda Provinsi Sumatera Selatan Jurnal 2010.

Saptarini D, $d k k, 2010$. Struktur Komunitas Gastropoda (Moluska) Hutan Mangrove Sendang Biru, Malang Selatan. Jurusan Biologi, FMIPA_ITS Surabaya, Indonesia.

Sinyo 2013. Studi Kepadatan dan keanekaragaman jenis Organisme Bentos pada Daerah Padang Lamun di Perairan Pantai Keluruhan Kastela Kecamatan Pulau Ternate: Unkhair Ternate. 